Article

\title{
Gendered Spaces Captured in Cultural Representations: Conceptualising the Indian Experience in Arundhati Roy's The Ministry of Utmost Happiness
}

\author{
Swapna Gopinath $\mathbb{D}$ \\ School for Media and Cultural Studies, Tata Institute of Social Sciences, Mumbai 400088, India; \\ gopinathswapna@rediffmail.com
}

Received: 4 September 2019; Accepted: 13 December 2019; Published: 19 December 2019

\begin{abstract}
Spatiality has emerged as a significant component in analyzing gendered experiences, and cultural expressions reveal this complex yet dynamic relationship in several ways. While some forms of art approach it in a direct, straightforward manner, literature does it, perhaps, in aesthetically diverse ways. Arundhati Roy has foregrounded the space and gender relationship in several ways, with language emerging as the most intricate tool to depict this relationship. Her second and latest novel, The Ministry of Utmost Happiness (2017) is a novel that has space as a prominent character and the gender identities, depicted in this novel, are challenging and interesting, especially in the context of modern India. From the transgender identity of the protagonist who resides in the heterotopic space of a cemetery to the female characters who sustain themselves in the conflict-ridden Kashmir valley, the novel experiments with possibilities using linguistic styles as the most appropriate and significant tool. Roy's experiments with form, with regards to gendered spatial experiences, will be explored in this paper. I will work within the framework of thirdspace and heterotopia as postulated by Soja and Foucault. This paper will analyse the depiction of gender within social spaces using the tools of Cultural Studies.
\end{abstract}

Keywords: heterotopia; thirdspace; literary geography; fictinal representations

\section{Introduction}

Gender is often experienced in spatial dimensions, and gender identities are performed in spaces. Patriarchal hegemony in India has a history of oppression and subjugation where body and space play prominent roles. Denying entry into spaces, controlling the female body by confining her to particular spaces, and demanding gendered expressions depending on spatial identity are all part of the history of gender-based identity politics in India. Intersectionality in the Indian context makes it challenging for the researcher to comprehend the complex relationship between gender and space. The new millennium witnesses gender oppression in new and multifarious forms. The truncated identities of postmodern, post-globalized Indian selves negotiate these dilemmas in distinctly unique ways and literary representations capture these new selves in multiple forms, sometimes by experimenting with semiotics and stylistic features.

India, with its multitudes whose destinies are mired in a complex socio-political, economical and, above all, religious environment, demands narratives that are multidimensional, within structures that encompass this complexity effectively. Hence creative writing in the context of India is a challenging task. Arundhati Roy's The Ministry of Utmost Happiness (2017) was released after a long period of hiatus after the publication of The God of Small Things (1997), which won the Booker Prize in 1997. The second novel garnered mixed reviews, due to its complex and rambling narrative, and its attempt 
to encompass the world of Indian social structure, with its caste and class identities along with gender conflicts. Roy's activism and social commitment has found its way into her creative writing space, with clever stylistic devices successfully employed to negotiate the socio-political issues polarising the nation in contemporary India.

\section{Introducing the Ministry of Utmost Happiness}

"I'll have to find a language to tell the story I want to tell," Roy said in an interview in 2011, as she discussed her return to fiction. "By language I don't mean English, Hindi, Urdu, Malayalam, of course. I mean something else. A way of binding together worlds that have been ripped apart" (Sehgal 2017). The Ministry of Utmost Happiness employs multifarious methods to narrate the story of fragmented lives in a land in conflict with its own people, and struggling to comprehend the polymorphous identities that define the nation. The novel tells the story of several people, from various parts of India, from Kerala to Kashmir, extending from the southern part of India to the northern part, and from Delhi to the forests in South India. It begins with the intersex person Aftab, who was born as a boy and later became Anjum, the lady who decides to live in the graveyard. The narrative shifts to Kashmir and to the story of an unconventional woman Tilothama, or Tilo, and her three friends, Naga, Biplab Dasgupta and Musa. The story has the voice of the subaltern and is a critique of the Indian social discourse that evolved out of the post-independent euphoria of an India striving to embrace principles of modernity and rationality. This novel negotiates with class, caste and gender identities, and the conflict that arises out of the aggressive monolithic identity of the Hindutva regime that seeks to erase the plurality that defines the nation.

Arundhati Roy's novels draw our attention to the spaces that are populated by the subalterns and to the voices from the margins, be it in her first novel The God of Small Things (1997) or in her second novel The Ministry of Utmost Happiness. According to Soja, postmodern feminism seeks a "consciously political grounding of critique and resistance in the spatiality of social life" (1996, p. 112) and Roy's novels do the same. Her fascination with the experience of subalternity and the articulations of resistance that constantly arise from these positions of subalternity shape the texture and structure of her novels. In both novels, she uses spatial identities as a tool to depict her concerns regarding her country. Even though her first novel is a close reading of the lives of a twin brother and sister, she has skillfully used the spaces that they inhabit to provide insights into the socioeconomic and political discourses that define the nation. With gender as a thematic concern in The Ministry, Roy adopts an innovative stance by introducing characters that break the stereotypes of gender. Spaces in India are constructed for heterosexual identities that are normative, and they tend to dictate the social relations that define these spaces. But Roy's protagonists defy these binaries of gender since they traverse a spectrum of gender identities, and their concerns, conflicts and interactions with spaces form the thematic framework of this novel.

Anjum, the Hijra, the intersex person, one of the protagonists in the novel, is introduced as living in the graveyard "like a tree" (Roy 2017, p. 1). "When people called her names-clown without a circus, queen without a palace-she let the hurt blow through her branches, like a breeze and used the music of her rustling leaves as balm to ease her pain" (Roy 2017, p. 1). She is left to survive in peace only when "Ziauddin, the blind imam ... befriended her and began to visit her" (1). Her uniqueness as a person is emphasised by the novelist. "It doesn't matter. I'm all of them. I'm Romi and Juli, I'm Laila and Majnu. And Mujna, why not? Who says my name is Anjum? I'm not Anjum, I'm Anjuman. I'm a mehfil, I'm a gathering. Of everybody and nobody, of everything and nothing. Is there anyone else you would like to invite? Everyone's invited" (Roy 2017, p. 2).

Tilo, another protagonist, is introduced as a woman who stands at odds with the social system and is introduced in Bhartiya's account thus: "This is S Thilothama. ... Sometimes she comes in the late night or in the early morning. She is always alone. She has no schedule" (Roy 2017, p. 131). Tilo is an elusive entity and social discourses demand a place, an identity for a person, and strive to place her in an environment, within a family, and in a geographic location. But with Tilo, "nobody seemed 
to be able to place her" (Roy 2017, p. 154). Rumours were rife about her family and her roots. "She didn't live in the hostel—she said she couldn't afford it. Instead, she lived in a shack in a nearby slum that was strung along the outer walls if an old ruin. None of us was invited to visit her" (Roy 2017, p. 155). According to the narrator, Biplab Das, she was the girl "who didn't seem to have a past, a family, a community, a people, or even a home" (Roy 2017, p. 155). Her present, like her past, is a non-conforming one where she remains on the margins, enjoying the freedom it offers her. Both Anjum and Tilo occupy spaces of an unconventional and nonconforming nature.

\section{Heterotopias and Gendered Spaces}

While discussing the critical interest in spatiality, as opposed to temporality, in the past, Foucault described alternate spaces, and called them heterotopias. He called them subversive spaces, as opposed to the illusory utopian spaces. They are spaces "capable of juxtaposing in a single real place, several spaces, several sites that are in themselves incompatible" (Foucault 1984, p. 6). He described a cemetery as a significant heterotopic space with a specific function. "The cemetery is certainly a place unlike ordinary cultural spaces. It is a space that is however connected with all the sites of the city, state or society or village, etc., since each individual, each family has relatives in the cemetery. In western culture the cemetery has practically always existed" (Foucault 1984, p. 5). Heterotopias are defined through their functionality and through their rules of accessibility, as well. "Heterotopias always presuppose a system of opening and closing that both isolates them and makes them penetrable. In general, the heterotopic site is not freely accessible like a public space. Either the entry is compulsory, as in the case of entering a barracks or a prison, or else the individual has to submit to the rites and purifications. To get in one must have a certain permission and make certain gestures" (Foucault 1984, p. 6). Heterotopias are typical spaces in a postmodern world, where fragmented individuals occupy carceral cityspaces.

\section{Heterotopias in Roy's Novel}

Roy has employed this concept of heterotopias to elaborate upon the subversive articulations of her protagonists. Several heterotopic spaces are used in the novel, and the graveyard which is Anjum's home is a typical heterotopic space that invites the Other to its premises. As Anjum decides to leave her lodging, Khwabgah, which is another heterotopic space like the graveyard, she is treated by a psychiatrist. Yet she changes residence, even though her adopted daughter Zainab refuses to accompany her, because Khwabgah can no longer accommodate her emotional state, after her traumatic experience in Gujarat. Heterotopias, in this novel, are built to sustain themselves against the onslaught of the national Hindutva politics. When the nation decides to intrude aggressively, an alternative space like Khwabgah becomes insufficient. Anjum is compelled to unearth heterotopias that defy the rules and values of the regular, surveyed city spaces.

"It was an unprepossessing graveyard, run-down, not very big and used only occasionally. Its northern boundary abutted a government hospital and mortuary where the bodies of the city's vagrants and unclaimed dead were warehoused until the police decided how to dispose of them" (Roy 2017, p. 58). The graveyard has a few drug addicts and homeless people occupying certain sections, but Anjum feels safe. "In that setting, Anjum would ordinarily have been in some danger. But her desolation protected her. Unleashed at last from social protocol, it rose around her in all its majesty-a fort, with ramparts, turrets, hidden dungeons and walls that hummed like an approaching mob" (Roy 2017, p. 61). The graveyard slowly transforms itself from "the fort of desolation" to a "home, a place of predictable, reassuring sorrow-awful, but reliable" (Roy 2017, p. 66). Anjum survives the visits from the municipal authorities by bribing them, moreover, the officials do not want to "run the risk of being embarrassed by her legendary abilities" (Roy 2017, p. 67). Anjum's "Jannat Guest House became a hub for Hijras who for one reason or another, had fallen out of, or been expelled from, the tightly administered grid of Hijra Gharanas" (Roy 2017, p. 68). The place, as a heterotopia, houses the Others like Dayanand, and Saddam Houssein, who is a Dalit. Soon it is Jannat Guest House 
and Funeral Services. When Tilo shifts residence with the baby, Miss Jabeen, we witness a world unraveling, which is strikingly different from the one outside- the Duniya, as Anjum calls it. The room given to Tilo is one which she has to share with "Comrade Laali, the dog and her family, Miss Jabeen and Ahlam Baji's grave" (Roy 2017, p. 304).

Shiraz cinema is another space discussed in the novel as a heterotopic space. It is a location in Kashmir, which was once a theatre where films were screened for the public and has since been converted into an interrogation centre for the Indian police force and the army. Roy has devoted several pages to elaborately draw this as a heterotopic space that outlines the politics of space. It is a paradoxical space, with its brightly lit "cheap, flashy chandeliers", posters advertising Cadbury products, faded film posters, the stale smell of "guns and diesel and old clothes", badly beaten up prisoners, soldiers and the muted sounds of torture from behind the walls. Roy critiques the unconstitutional methods of oppression when she says: "Cement kangaroos with mirthless smiles and garbage-bin pouches that said Use Me supervised the kangaroo court" (Roy 2017, p. 331).

\section{Heterotopias and Thirdspaces}

If Foucault's heterotopias were "countersites," where real sites were "represented, contested and inverted," Soja, through his thirdspace, brought "a rigour and definition" to the concept of heterotopias (Foucault 1984, p. 7; Maier 2013, p. 82). Soja's work on spaces altered our perception of space and social structures in a radical manner. His introduction of the concept of thirdspace is an innovative way of comprehending spatialities. According to Soja, firstspace is all about geographical placing, secondspace is about the manner in which we perceive those spaces, and Thirdspace is the complex ways in which we occupy these spaces. Thirdspace is, therefore, an agglomerate of everything that constitutes the experience of living — it is the history, the myth, the dream, the imagination, and the craft that defines the experience of living in a space.

Soja says: "We are first and always historical-social-spatial beings, actively participating individually and collectively in the construction and production of - the 'becoming' — of histories, geographies, societies" (1996, p. 72). The shift from epistemology to ontology, in the context of comprehending the relation between spatiality, sociality and historicity, is foregrounded in the concept of thirdspaces. (Soja 1996, p. 81). According to Soja, "thirdspace is the space where all places are, capable of being seen from all angles, each standing clear; but also a secret and conjectured object, filled with illusions and allusions, a space that is common to all of us yet never able to be completely seen and understood, an 'unimaginable universe'" (Soja 1996, p. 56). Thirdspace is a fluid and constantly evolving space. "Everything comes together in thirdspace: subjectivity and objectivity, the abstract and the concrete, the real and the imagined, the knowable and the unimaginable, the repetitive and the differential, structure and agency, mind and body, consciousness and the unconscious, the disciplined and the transdisciplinary, everyday life and unending history" (1996, pp. 56-57). Soja says that a thirdspace perspective has in it an "epistemological and theoretical critique that revolves around disruptions and disorderings: of difference, of confidently centred identities, and of all forms of binary categorization" (1996, p. 107). In the context of thirdspaces, spaces are fluid and blend materiality with the world of the ephemeral. Thus, space is construed around a shared past and narrative that is part of the community's history, shared by the readers and the writer. The rhizomatic assemblages that create space and its fictional representations, evolve and assume a certain identity through interactions between them that are dynamic and complex. In this novel, thirdspace as a perspective emerges as an important tool to comprehend this space, the postcolonial Indian society, with its plurality, and the multiplicities that intersect and define the social structures. The novel imagines thirdspaces capable of highlighting the social discourses that accommodate caste heirarchies, gender inequalities and similar acts of subjugation and oppression within post-global India. Gender, in these thirdspaces, emerges as a prominent idea and experience in this novel through the depiction of physical spaces, including the bodies of the protagonists. 


\section{Gender and Thirdspaces in Roy's Novel}

Roy's works read into spatial experiences as complex dialectical processes, constantly interacting with the protagonists' gender, class and caste consciousness. With regards to the dialectics between gender identities and space, Roy leads the reader through the streets of Delhi, Kashmir and a few other spaces characteristically unique in nature. Roy seems to agree with the observation that "nowhere is the tendency to gender space as evident in colonial, postcolonial and neocolonial spaces" (Wrede 2015, p. 13). The plurality of gender identities and the spaces they occupy and imagine in contemporary India are carefully assimilated into the narrative. Accordingly, Tilo is a woman who has embraced the spaces of the city as a source of solace from her restlessness. The apartment that Tilo occupies belonged to Das and, in her description of Tilo's house, Roy builds an interesting contrast with Anjum's living spaces. For Tilo, experiences of spaces as a woman are definitely difficult, yet they are not as traumatising as the experiences of transgender persons like Anjum. Tilo's subalternity arises from her close association with terrorists like Musa, her active role in acts of resistance and her non-conformative modes of everyday life.

Unlike Tilo, Anjum's experience is more traumatic and conflict-ridden. Anjum was born as Aftab, as the long-awaited son, to Jahanara Begum in Delhi. For the mother, "everything was either masculine or feminine, man or woman. Everything except her baby" (Roy 2017, p. 8). In Aftab's case, the child's gender defied expression—no language Jahanara knew could be used to explain her son's condition. "Was it possible to live outside language? Naturally, this question ... addressed itself to her as a soundless, embryonic howl" (Roy 2017, p. 8). Young Aftab's childhood is a regular one but as he grows older, his world begins to alter significantly. As a person conforming to the male gender, his life is far simpler and fits into the pattern of binaries. But spaces begin to shift as far as the young Aftab is concerned, as his identity as an individual emerges as a questionable one. From his mother's protective eyes, his foray into the real world is hugely challenging for the young boy. At the music class, the boys begin to tease and ridicule his shy feminine voice. "He's a She. He's not a He or a She. He's a He and a She. She-He, He-She Hee! Hee! Hee!" (Roy 2017, p. 12). When Aftab's father is confronted with this gender fluidity, Mulaqat Ali decides to intervene, preferring the identity of the boy in Aftab. The doctor's revelation decides the matter. "Aftab, he said, was a rare example of a hermaphrodite, with both male and female characteristics, though outwardly, the male characteristics appeared to be more dominant" (Roy 2017, pp. 16-17). Aftab did not belong to the well-defined spatial patterns, so he scouted out alternatives, alternate spaces.

Aftab soon realised the Other spaces and identities, and eagerly sought out those spaces willing to accommodate him. "One spring morning, Aftab saw a tall, slim-hipped woman wearing bright lipstick, gold high heels and a shiny, green satin salwar kameez" (Roy 2017, p. 18). Aftab's exploration of spaces that will release him from his identity as a man culminated in his discovery of the dwelling place of the beautiful and bold woman he had seen in the street. "He followed her down the street all the way to Turkman Gate and stood for a long time outside the blue doorway she disappeared into" (Roy 2017, p. 18). The dialectics that link spaces, both material and corporeal, is clearly emphasized in the case of Aftab. "Ordinary women in Shajahanabad wore burqas or at least covered their heads and every other part of their body except their hands and feet. The woman Aftab followed could dress as she was dressed and walk the way she did only because she wasn't a woman. Whatever she was, Aftab wanted to be her" (Roy 2017, pp. 18-19). Aftab's destination was the haveli called the "Khwabgah-the House of Dreams" (Roy 2017, p. 19). His choice of his living space is integral to his gender affiliation. "Finally the day dawned when ... he entered that ordinary broken-down home as though he were walking through the gates of Paradise" (Roy 2017, p. 20). Aftab experiences a sense of inclusion through acceptance into a space like Khwabgah. The place is in a dilapidated condition and is typically representative of the Othering that marginalises the other genders. The novelist gives a detailed description of the house which is to be the home for Aftab/Anjum for several years to come. In Khwabgah, transgender persons occupy rooms that are better than the rest, while the regular, normative gender category withdraws into the kitchen spaces. 
Kulsoom Bi is the head of the household and has specific ideas about the place. "This house, this household, has an unbroken history that is as old as this broken city," she said. "These peeling walls, this leaking roof, this sunny courtyard-all this was once beautiful ... We are not just any hijras from any place. We are the hijras of Shajahanabad" (Roy 2017, pp. 48-49). The house functions efficiently through this "use and demarcation of space (which) is integral to the exercise of power" and Kulsoom Bi highlights the uniqueness of this place that assumes its power from the exceptional identity of its inhabitants (Spain 1992, p. 324). "The Khwabgah was called Khwabgah, ..., because it was where special people, blessed people, came out with their dreams that could not be realized in the Duniya. In the Khwabgah, Holy Souls trapped in the wrong bodies were liberated" (Roy 2017, p. 53). The novel is not just a subversion of hegemonic relations between space and gender, it is also a "a genuine paean for the patched integrity of the dispossessed and brutalised" (Lahiri 2017). As a thirdspace, the house offers solace to Aftab, whose gender fluidity acts as a symbol of the immense possibilities of this space. Moreover, spaces can be oppressive, and Anjum and Tilo, through their negotiations with space, find themselves empowered. "At the age of fifteen, only a few hundred yards from where his family has lived for centuries, Aftab stepped through an ordinary doorway into another universe" (Roy 2017, p. 25). Aftab's choice of residence reminds us of Castells's observation: "Questions of gender, sexual orientation and ethnicity are now seen as sites of resistance and struggle as much as class" (Castells 1983, p. 104).

\section{Gendering Spaces}

Accordingly, thirdspaces permit not only expressions of resistance but also interactions and flows, where subjectivities are molded in dynamic ways. Gendered identities negotiate within these spaces and interact with them, as mentioned by Massey: "From the symbolic meaning of spaces/places and the clearly gendered messages which they transmit, to the straightforward exclusion by violence, spaces and places are not only themselves gendered, but, in their being so, both reflect and affect the ways in which gender is constructed and understood" (Massey 1999, p. 179). While reading the novel, one encounters the processes employed by Roy to accentuate the presence of the city as a thirdspace. Roy speaks of Delhi as a woman, "a thousand-year old sorceress" with her "Medusa skull", "loose, parchment skin", "wrinkles" and "arthritic joints a crumbling amphitheatre", where stories of human adventures and encounters are enacted out. (Roy 2017, p. 96) Roy goes on to describe the attempts of the rulers of the nation to transform her into a young and attractive woman, to resurrect her in a new form. She describes it "as the summer Grandma became a whore" (Roy 2017, p. 96).

Anjum in public urban spaces defies the binaries that define cityspaces. 'She (Anjum) who never knew ... which queue to stand in, which public toilet to enter .... augmented by her ambiguity" attempts to delineate her identity in the city. (Roy 2017, p. 122) When Anjum and Nimmo, another hijra, decide to visit the city streets, they venture out at night. They prefer to be among smaller crowds of people, and Anjum carefully selects her clothes for the occasion. "Anjum had dressed down, in one of her drabber Pathan suits, though she could not resist a hairclip, a dupatta and a touch of lipstick" (Roy 2017, p. 108). When the documentary makers who are documenting the protest and resistance on the streets encourage Anjum to speak up and to describe the other world, she merely says, "We've come from another world" (Roy 2017, p. 110).

During this visit to the streets of Delhi, the confrontation between Aggarwal, the accountant fighting against corruption, and Anjum, over the abandoned baby, is a significantly striking incident in this context of thirdspaces and gendered bodyspaces. "He, a revolutionary trapped in an accountant's mind. She, a woman trapped in a man's body. He, raging at a world in which the balance sheets don't tally. She, raging at her glands, her organs, her skin, the texture of her hair, the width of her shoulders, the timbre of her voice" (Roy 2017, p. 122). Her victory over him is through Ishrat, another hijra, and the victory is marked by a clear possession of the space through her identity as a hijra. "She started the spread-fingered Hijra clap and began to dance, moving her hips obscenely, swirling her 
chunni, her outrageous, aggressive sexuality aimed at humiliating Mr. Aggarwal, who had never in all his life fought a fair street fight" (Roy 2017, p. 123).

Unlike Anjum, Tilo discovers another relationship with space. Tilo, as the woman who stubbornly refuses to comply with social norms, also enjoys a greater control over her space compared to other women who conform to social norms. In Delhi, Tilo owns her space, even though it is a precarious one, and has a shady, criminal background. Tilo is a non-conforming female and hence finds her own space, to explore and to reflect upon, and she feels the urge to be present in a conflict zone like Kashmir to assimilate her gendered experience in space. In Kashmir, the novelist installs two women characters, Tilo and Khadija, and builds a narrative out of their spatial encounters. Kashmir is presented as a distinctly different space, where identity emerges as a significant marker. Subalternity in this context often transcends gender, yet remains a strong presence in this conflict zone that makes everyday living an act of resistance.

For Tilo, the subversive image of Indian womanhood, Kashmir is a place she understands as her lover and a wanted terrorist-Musa's space where he watches "over her, from his hidden perch" (Roy 2017, p. 270). She is visited by "friendly souls", welcoming her to their homes and showering her with the love they have for Musa (Roy 2017, p. 270). Her memories of the place are a private, intimate aspect of her life, and every visit to Kashmir is therefore special. "The truth is that she travelled back to Kashmir to still her troubled heart, and to atone for a crime she hadn't committed. And to put fresh flowers on Commander Gulrez's grave" (Roy 2017, p. 270). Tilo's first visit to Kashmir is carefully charted, with the novelist detailing the land and its response to the conflict that has been shaping its identity. The silence and the tension that is the result of the heavy surveillance-the acknowledgement of the intruding eyes of the military into the lives of the citizens, into their thought processes-has created a community of individuals, living within the "rifle-sights of a soldier" (Roy 2017, p. 347). Living in a conflict zone is a dangerous proposition for all genders. For Musa's wife and his daughter, like several other Kashmiri women, even their own houses and their balconies are unsafe. Intimate spaces are intruded upon by the military and the militants, making their existence precarious. Musa's wife and daughter are killed in a tragic incident when they are shot at during an attack on the militants by the army.

Another space elaborately portrayed is Khwabgah which, as a gendered space, is an empowering one for the transgendered persons. Roy strikingly imagines the space as a refuge for Aftab, who finds his refuge from the normative gender binaries that define the world outside. Khwabgah has its norms and rules strictly adhered to, and, within its boundaries, it embraces the Other, the intersex, the hijra, and offers a social bond that is deep and intense, creating a community among the conflicted souls within the gendered bodies. Khwabgah, as a thirdspace, transcends the established norms of spatial identities and emerges as a fluid entity enfolding its materiality within itself, as well as the ephemerality of subjectivities that occupy the space.

The novel also narrates the experiences of other women like R C's wife, who encounter space as a conforming, restricting entity. When $\mathrm{R} \mathrm{C}$ tells Naga about disciplining women through physical violence, he is startled. "Outwardly she looked placid and perfectly content with her lot-with her houseful of mementoes and her collection of somewhat tasteless jewelry and expensive Kashmir shawls. He couldn't imagine that she was really a volcano of hidden furies that needed to be disciplined and slapped from time to time" (Roy 2017, p. 232). Spaces are envisioned through the experiences of the protagonists, as well as through explicit images of locations where the story unfolds. The cityscapes, described elaborately by Roy, are explicitly linked to gender relations and identities. Roy makes this explicit through sentences like this: "Right beside the school gate on which a painted nurse was giving a painted baby a painted polio vaccination, a circle of sleepy women, migrant workers from roadworks nearby, stood around a tiny boy as he squatted like a comma on the edge of an open manhole" (Roy 2017, p. 301). Thirdspaces in Roy are not limited to these actual spaces within the city, the streets, and the houses; the bodies of the protagonists are also foregrounded as spatial beings, capable of subverting normative systems of power. 


\section{Body as a Space}

"Our performance as spatial beings takes place at many different scales, from the body ... to a whole series of more distant geographies" (Mumford 1989, p. 6). Gendered bodies and spaces are socially constructed and are defined through their performative qualities. The dynamic interactions between spaces and gendered selves result in paradigm shifts, and are often in response to the hegemonic centres of power that dictate the normative and ideological discourses of the nation. "There is a revived interest in the body as the most intimate of personal-and-political spaces, an affective microcosm for all other spatialities" (Soja 1996, p. 112). The body as a space, in the context of conflict-ridden countries, is a trope that captures the structural violence capable of challenging the national identity of a nation. The militants' dead bodies are political weapons and become part of the spectacle where the people of the land gather to mourn and throw flowers at the procession. Nakedness, even within bedrooms, becomes a lethal freedom. The possibility of the military intruding into the lives of the people, and the fear of being uprooted from the land, keep them constantly on guard. Musa calls it a protocol to sleep fully dressed. Musa, as an enemy of the state, lives in hiding, under constant threat of being killed. But his lover, Tilo, as a woman, feels free to roam around Kashmir, although she is more restrained in Delhi, where she has to keep herself healthy and strong to ward off the inebriated and dangerous bosses, the men who stalk her and try to take advantage of her public image as a woman who refuses to conform. "She was a lone woman who was immodestly attired and smoked cigarettes, and there was nothing to suggest that she came from a 'decent' family who would rise to her defense" (Roy 2017, p. 364). At Shiraz cinema in Kashmir, Tilo has to encounter the torture methods of ACP Pinky, who is forbidden from leaving any "injury marks" (Roy 2017, p. 381). ACP Pinky had found a cheap, cliched way around her problem. She called on a "primordial punishment for the Woman-Who-Must-Be-Taught-A-Lesson" (Roy 2017, p. 383): Tilo's long hair was shaved off. Amrik Singh's act of kindness, powdering her scalp, which is in fact a lecherous act for Tilo, who is forced to obey, sits meekly. The forcibly shaven scalp and the powdering of it by Amrik Singh are acts of violence on the woman's body.

In Kashmir, women are extremely vulnerable, and stemming from this vulnerability is their courage to step out onto the streets and carry on with their lives. Khadija is a Kashmiri woman who reminds Tilo of their endurance and inner strength. The salwar kameez, the pheran and the hijab give them a sense of security which Tilo admires. The country, which is torn by years of conflict, implies multiple dimensions of oppression as far as women are considered. "Women are not allowed. Women are not allowed. Women are not allowed" (Roy 2017, p. 187). Roy writes this in italics. Tilo doesn't ask Khadija about the restrictions and inequalities that are rife in the social life of the Kashmiri women, yet the question arises repeatedly in her mind. Another notable instance where Roy addresses the complex nature of relations between space and body is the incident of Tilo's decision and the procedure related to MTP or medical termination of pregnancy. At the hospital, it is an act that is looked down upon by everyone, including the doctor, especially when the woman is unaccompanied by her 'guardian'. There is "hostility and disgust" (Roy 2017, p. 392). The doctors disapprove of it and lecture her about the procedure being unsafe. The whole experience is a nightmare and her body is subjected to pain, both physically and emotionally.

Bodily experiences contextualized in physical spaces create thirdspaces, and the novelist succeeds in blending social histories with these spaces. The story of Miss Jabeen's mother, Comrade Revathy, is also the story of the structural violence that is part of contemporary India and its impact on the bodies of the poor women who are part of backward communities-both economic and religious backwardness-resulting in large scale violence against their bodies that remains unheard and unaddressed. Revathy's child is born out of a gang rape, and both her oppressors as well as her fellow comrades are equally oppressive. Revathy, in a letter, narrates similar instances of other women truamatised by acts of violence committed against them, their bodies being easy targets, even in the rural areas and jungles of India. 
Women who survive this gendered spatial violence sometimes are perpetrators of violence as well, as in the case of ACP Pinky. Her body is a space marked by her gender and her identity as the sister of a person killed by terrorists. Tilo is one of the "ladies" caught, along with a militant, Commander Gulrez, and ACP Pinky Sodhi is the "brutal interrogator" who seamlessly fits into the police force through her violent and inhuman methods of interrogation (Roy 2017, p. 177). It is said that "no one had ever seen her out of the uniform" (Roy 2017, p. 177). Though Pinky exercised restraint, since Tilo was not a Kashmiri, she did not leave her without punishment, and opted for a haircut, which the novelist sees as a clever way to challenge conventional identity markers. "The haircut-the shave-must have been ACP Pinky Sodhi's idea. A policewoman's therapy for what she saw as treason-sleeping with the enemy" (Roy 2017, p. 184).

In this context, Ranade observes thus: "Different bodies experience space differently depending on, among other things, their gender, age, sexuality, and physical disability because access to space is socio-culturally determined by these factors" (2007, p. 1520). Anjum, and intersex people like her, faces harsh ordeals in this context. "Anjum lived in the Khwabgah with her patched-together body and her partially realized dreams" (Roy 2017, p. 29). Even medical intervention to fix her condition as a hermaphrodite doesn't control her agony. "The riot is inside us. The war is inside us. Indo-Pak is inside us. It will never settle down. It can't" (Roy 2017, p. 23). When Anjum gets lost in the outside world, the contemporary India, which polarises society foregrounding a politics founded on Hindutva, the trauma rips her apart. It is beyond description, and the Anjum that returns is drastically different, physically and emotionally. "She had had a haircut. What was left of her hair now sat on her head like a helmet with ear muffs. She was dressed like a junior bureaucrat in a pair of dark brown men's terry cotton trousers and a checked, short-sleeved safari shirt. She had lost a good amount of weight" (Roy 2017, p. 46). She is cold and distant, and she soon transforms Zainab too, without seeking her opinion or consulting the other members at Khwabgah. "She returned with a completely transformed Zainab. Her hair was cropped short and she was dressed in boy's clothes, a baby Pathan suit, an embroidered jacket, jootis with toes curled up like gondolas" (Roy 2017, p. 48). This transformation is the result of a fear, deep seated and stemming from insecurity. In the context of material space, this can be related to the transgression of boundaries. In the socio-spatial schema of gender, the boundaries of permissible behaviour are strictly delineated. Any transgression of spatial boundaries is deemed as a challenge to the status-quo and liable to be punished. The production of safety through respectability is thus practised by women in their everyday movement through public spaces. Sometimes, in safe environments, their actions are purposeful and conscious. At other times, they are the result of a subconscious self-policing arising from an internalisation of the hegemonic notions of femininity which determine what is proper and what not. (Ranade 2007, p. 1523) Roy clearly incorporates this idea, saying that, "it is through the body that the spatio-temporal regulations of social structure are produced, reproduced, represented and transformed" (Ranade 2007, p. 1525). This is evident in the character of Mariyam Ipe, Tilo's mother who is an educationist, successful as a woman, yet shares a strained relationship with her daughter. Her social status and her identity as a human being are cruelly altered when she becomes sick and delusory. While in hospital, she utters the foulest language. The nurses comfort Tilo, saying that it is the disease that is conversing through the frail old body of the mother. It is "someone else. Her illness. Her blood. Her suffering. Our conditioning. Our prejudices, our history ..." (Roy 2017, p. 253). These thirdspaces unravel the socioeconomic and political discourses in diverse ways; the novel thus becomes a commentary on the nation.

\section{Conclusions}

Thirdspaces are dynamic spaces where cartographies and representations blend and create a vibrant socio-cultural experience of living. Spaces emerge as significant markers, as part of the processes of social ostracisation and marginalisation, and gender complicates matters further. Gendered experiences of spatial identities are complex and are integral to cultural representations. Gender performances act as a key component defining these spaces, and any study of social life will only 
be comprehensive if these aspects are taken into account. Depicting the experiences of marginalised gender identities as thirdspace experiences effectively captures their struggles, their acts of subversion and their incessant tales of resistance. Their consistent struggles deterritorialise and reterritorialize, thereby reshaping the assemblages that mold human existence in societies. While woman are seen as the Other-an established identity, the marginalised Other that helps build the binary seems to coexist with the hegemonic class, constantly subverting and resisting hegemonic conventions and social relations-it is the other gender identities in the wider spectrum that struggle to maintain their identity. They segregate and build their own social connections and heirarchies, creating heterotopias struggling to survive the normative structures governing societies. Literary representations, when they strive to imagine the interrelatedness of space and gender, emerge as significant cultural tropes of any particular historical moment, as in the case of Arundhati Roy's novel, discussed in this work.

Funding: This research received no external funding.

Conflicts of Interest: The author declares no conflict of interest.

\section{References}

Castells, Manuel. 1983. The City and the Grassroots: A Cross-Cultural Theory of Urban Social Movements. Berkeley and Los Angeles: U of California P.

Foucault, Michel. 1984. Of Other Spaces: Utopias and Heterotopias. Architecture. Available online: http: //web.mit.edu/allanmc/www/foucault1.pdf (accessed on 10 August 2018).

Lahiri, Oeendrila. 2017. The Ministry of Utmost Happiness is Timely, but not deserving of the Booker. The Wire. Available online: https://thewire.in/books/ministry-utmost-happiness-arundhati-roy (accessed on 12 October 2018).

Maier, Harry O. 2013. Soja's Thirdspace, Foucault's Heterotopia and de Certeau's Practice: Time-Space and Social Geography in Emergent Christianity. Historical Social Research 38: 76-92.

Massey, Doreen. 1999. Space, Place and Gender. Minneapolis: U of Minnesota P.

Mumford, Lewis. 1989. The City in History: Its Origins, Its Transformations, and Its Prospects. San Diego, New York and London: Harvest Book.

Ranade, Shilpa. 2007. The Way She Moves: Mapping the Everyday Production of Gender-Space. Economic and Political Weekly 42: 1519-26.

Roy, Arundhati. 2017. The Ministry of Utmost Happiness. Gurgaon: Hamish Hamilton.

Sehgal, Parul. 2017. Arundhati Roy's Fascinating Mess. The Atlantic. Available online: https://www.theatlantic. com/magazine/archive/2017/07/arundhati-roys-fascinating-mess/528684/ (accessed on 10 October 2018).

Soja, Edward W. 1996. Thirdspace: Journeys to Los Angeles and Other Real-and-Imagined Places. Cambridge: Blackwell Publishers.

Spain, Daphne. 1992. Gendered Spaces. Chapel Hill and London: University of North Carolina Press.

Wrede, Theda. 2015. Introduction to Special Issue "Theorizing Space and Gender in the 21st Century". Rocky Mountain Review 69: 10-17.

(C) 2019 by the author. Licensee MDPI, Basel, Switzerland. This article is an open access article distributed under the terms and conditions of the Creative Commons Attribution (CC BY) license (http://creativecommons.org/licenses/by/4.0/). 